\title{
Evaluation of the fluoride stability of dentifrices sold in Manaus, AM, Brazil
}

\author{
Estabilidade do fluoreto de dentifrícios comercializados em \\ Manaus, AM, Brasil
}

\author{
Nikeila Chacon de Oliveira Conde* \\ Maria Augusta Bessa Rebelo** \\ Jaime Aparecido Cury $* * *$
}

\begin{abstract}
The minimum requirement for the anti-caries effect of a dentifrice is the presence of available and stable fluoride in the formulation. The concentration of available fluoride in the major dentifrices sold in Brazil has been reported, but few data have been published about its stability, which is temperature-dependent. Thus, the aim of this study was to evaluate the concentration and stability of fluoride in dentifrices sold in Manaus, AM, Brazil, which is a typical tropical city. The concentrations of total fluoride, total soluble fluoride, MFP, and of insoluble fluoride of six Brazilian dentifrices and an imported one were analyzed. The analyses were made when the dentifrices were purchased and during a year of storage at room temperature $\left(28.9 \pm 1.16^{\circ} \mathrm{C}\right)$ and under refrigeration $\left(26.3 \pm 0.88^{\circ} \mathrm{C}\right)$. The analyses were performed using an ion specific electrode Orion 96-09. At the time of purchase, all the dentifrices analyzed showed more than 1,000 ppm $\left(\mu \mathrm{g} \mathrm{F}^{-} / \mathrm{g} ; \mathrm{w} / \mathrm{w}\right)$ of soluble fluoride. However, in most of them, this form of fluoride was not shown to be stable. The highest loss of soluble fluoride was found for storage at room temperature, reaching up to $40 \%$. Although all dentifrices comply with the Brazilian guidelines with regard to the concentration of total fluoride (maximum of $0.15 \%$ ), the instability of soluble fluoride observed in some of them can impair their anti-caries effect and this condition is not contemplated in the Governmental rules.
\end{abstract}

DESCRIPTORS: Dentifrices; Fluorine; Toothpaste; Fluorides.

RESUMO: O requisito mínimo para que um dentifrício tenha potencial anticárie é ele ter uma formulação com fluoreto na forma solúvel e estável. A concentração de fluoreto solúvel nos dentifrícios vendidos no Brasil tem sido descrita, mas pouco é conhecido sobre sua estabilidade, a qual é função da temperatura. Assim, o objetivo deste estudo foi avaliar a concentração e estabilidade do fluoreto em dentifrícios vendidos em Manaus, AM, Brasil. As concentrações de fluoreto total, fluoreto solúvel total, MFP, e de fluoreto insolúvel de seis dentifrícios nacionais e um importado foram determinadas quando da aquisição e durante um período de 12 meses de armazenamento à temperatura ambiental $\left(28,9 \pm 1,16^{\circ} \mathrm{C}\right)$ e sob ar refrigerado $\left(26,3 \pm 0,88^{\circ} \mathrm{C}\right)$. Para a análise foi utilizado eletrodo específico para íon fluoreto

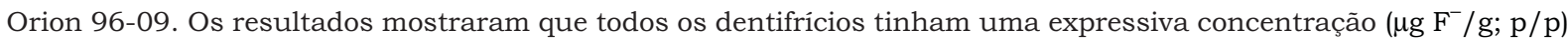
de fluoreto solúvel total quando da aquisição. Entretanto, a maioria deles não se mostrou estável quando do armazenamento. A maior perda ocorreu à temperatura ambiente, atingindo valores de $40 \%$. Embora a concentração de fluoreto total encontrada em todos os dentifrícios esteja de acordo com a portaria da ANVISA, dependendo das condições de armazenamento a perda de fluoreto solúvel pode comprometer o efeito anticárie de alguns dentifrícios e isto não está contemplado pela portaria brasileira em vigor.

DESCRITORES: Dentifrício; Flúor; Creme dental; Fluoretos.

\section{INTRODUCTION}

The decline in the prevalence of dental caries observed over the last few decades of the $\mathrm{XX}^{\text {th }}$ Century has been attributed largely to the use of dentifrice, which is considered the best method of using fluoride because the teeth are simultaneously cleaned with the purpose of promoting oral health ${ }^{10}$. However, in order for the dentifrice to be efficient, it is important that the fluoride be soluble in the formulation and regularly present in the oral cavity in order to interfere with the phenomena of enamel-dentine demineralization and remineralization $^{21}$.

The majority of dentifrices contain fluoride in their composition in the ionic free form $\left(\mathrm{F}^{-}\right)$of $\mathrm{NaF}$, or ionizable in the form of sodium monofluorophosphate (MFP), which are considered active

\footnotetext{
*Assistant Professor of Stomatology; **Associate Professor of Stomatology - Department of Dentistry, Federal University of Amazonas.

***Professor of Biochemistry, School of Dentistry of Piracicaba, State University of Campinas.
} 
Conde NCO, Rebelo MAB, Cury JA. Evaluation of the fluoride stability of dentifrices sold in Manaus, AM, Brazil. Pesqui Odontol Bras $2003 ; 17(3): 247-53$.

forms for controlling caries ${ }^{18}$. These must be in the dentifrice in a soluble form to guarantee activity against caries ${ }^{1}$. However, depending on the formulation, part of the fluoride may be inactive ${ }^{5}$ and this occurs mainly in the presence of calcium $\left(\mathrm{Ca}^{++}\right)$and $\mathrm{F}^{-}$ions. On the other hand, although MFP is more stable in the presence of $\mathrm{Ca}^{++}$, because fluoride is linked covalently to phosphate, MFP undergoes hydrolysis over time and releases $\mathrm{F}^{-}$, which reacting with $\mathrm{Ca}^{++}$will form insoluble fluoride that is inactive against caries ${ }^{5}$. It should be emphasized that the dentifrices that represent approximately $90 \%$ of the daily Brazilian consumption contain $\mathrm{Ca}^{++}$because they are formulated with $\mathrm{MFP} / \mathrm{CaCO}_{3}{ }^{11}$.

Thus, in 1989 in Brazil, guidelines were established by the Secretary for Sanitary Vigilance to regulate the concentration of fluoride in dentifrices and guarantee their quality in caries control. However, these rules have undergone changes since 1996, and the Resolution No. 79 of August 28, $2000^{3}$, which is in force, abolished the need for dentifrice to show soluble fluoride. This resolution only establishes the maximum fluoride content $(0.15 \%)$ that is permitted in a dentifrice, without specifying quality. In addition, it admits low solubility salts, like calcium fluoride, for example, to be used in dentifrice, which would result in a formulation with a maximum of $8.0 \mathrm{ppm}$ soluble fluoride.

The evaluation of fluoride concentration in dentifrices sold in Brazil has been followed up since $1980^{4}$, and up until 1988 only $25 \%$ of those consumed were fluoridated ${ }^{8}$. Currently, $99 \%$ of them contain fluoride and although there are over 30 brands, five of them represent $92 \%$ of Brazilian consumption. The consumption of dentifrices in Brazil is $1.45 \mathrm{~g} /$ day/person ${ }^{9}$ and if these five dentifrices were adequately fluoridated, the majority of the population would have anti-caries benefits. The majority of the dentifrices are manufactured in the State of São Paulo and an analysis of these five, in samples collected in the five Brazilian regions, showed a significant concentration of soluble fluoride in all of them ${ }^{11}$, but the stability was not evaluated. Recently these five dentifrices were analyzed and it was found that in the majority of them, the soluble fluoride concentration found was lower than the total reported on the packa ging ${ }^{17}$. In addition, a dentifrice launched on the market during the term of the current administrative ruling was analyzed, and $60 \%$ of its total fluoride was found to be in insoluble form bound to the abrasive ${ }^{19}$. However, both in a study by Duarte et al. ${ }^{11}$ (1999) and in another by Orth et al. ${ }^{18}$ (2001), the stability of the fluoride was not evaluated. Furthermore, with age there is a considerable loss in the soluble fluoride concentration found in dentifrices, which is accelerated with the increase of temperature ${ }^{13}$.

This being so, the aim of this study was to evaluate the availability and stability of fluoride in dentifrices purchased and consumed in Manaus, AM, Brazil, considering the distance from the dentifrice producer industries, situated in the State of São Paulo, as well as the climatic conditions of this city.

\section{MATERIALS AND METHODS Samples and experimental design}

The five dentifrices most consumed on the Brazilian market were purchased in the City of Manaus trading center from two large supermarkets. The imported dentifrice Crest $^{\oplus}$ was also acquired, as it is recognized by the American Dental Association (ADA) as being anti-caries, and also the dentifrice Tandy $^{\circledast}$, as being representative among the infant Brazilian public. Table 1 gives the characteristics of the dentifrices, as informed on the packaging.

For each dentifrice analyzed, 12 tubes were stored in two groups. The first group, composed of six tubes of each brand, was kept in an air conditioned environment, simulating a large size commercial establishment. The second group was stored at a residential ambient temperature. The analyses were carried out at the time of acquisition and after 4, 8 and 12 months (August/97 to July/98) for the two groups.

The temperatures were recorded daily at the following times: 8:00, 12:00 and 18:00 $\mathrm{h}$, and the monthly average was calculated.

\section{Determination of the fluoride concentration in dentifrices}

The analyses were done in duplicate, basically using the procedure described by $\operatorname{Cury}^{6}(1987)$ and modified by Orth et al. ${ }^{17}$ (2001). In this study calibration curves were made with standard fluoride solutions containing from 0.5 to $4.0 \mu \mathrm{g} \mathrm{F}^{-} / \mathrm{ml}$; an electrode (Orion 96-09) and an ion analyzer (Orion 720A) were used.

The following concentrations were determined: (1) total fluoride (TF), which represents the sum of the total soluble fluoride concentrations plus the 
Conde NCO, Rebelo MAB, Cury JA. Evaluation of the fluoride stability of dentifrices sold in Manaus, AM, Brazil. Pesqui Odontol Bras 2003;17(3):247-53.

TABLE 1 - Specifications of dentifrices analyzed, as described on packaging.

\begin{tabular}{l|c|c|c|c}
\hline \hline $\begin{array}{c}\text { Dentifrice brand } \\
\text { name }\end{array}$ & $\begin{array}{c}\text { Fluoride concentration } \\
(\mu \mathrm{g} / \mathrm{g})\end{array}$ & $\begin{array}{c}\text { Fluoridating } \\
\text { agent }\end{array}$ & $\begin{array}{c}\text { Lot and year of } \\
\text { manufacturing }\end{array}$ & $\begin{array}{c}\text { Expiry } \\
\text { time }\end{array}$ \\
\hline Close-up $^{\oplus *}$ & 1,000 & MFP & $46200230 / 97$ & $06 / 2000$ \\
\hline${\text { Colgate } \mathrm{MFP}^{-C a}{ }^{\oplus * *}}^{\text {Crest }^{\oplus *}}$ & 1,450 & MFP & $2601 / 96$ & $11 / 1999$ \\
\hline Gessy $^{\oplus * *}$ & 1,100 & NaF & $6344 \mathrm{GE} / 96$ & $12 / 1999$ \\
\hline Signal $^{\oplus * *}$ & 1,500 & MFP & $3780220 / 97$ & $07 / 2000$ \\
\hline Sorriso $^{\varpi_{* *}}$ & 1,500 & MFP & $42700220 / 97$ & $09 / 2000$ \\
\hline Tandy $^{\oplus *}$ & 1,500 & MFP & $11 / 97$ & $06 / 2000$ \\
\hline \hline
\end{tabular}

*Silica or ${ }^{* *}$ calcium carbonate as abrasive.

insoluble (linked to the abrasive); (2) total soluble fluoride (TSF), representing the ionic free fluoride $\left(\mathrm{F}^{-}\right)$plus the ionizable in the form of MFP and (3) soluble fluoride in the free form $\left(\mathrm{F}^{-}\right)$. From these analyses the MFP and insoluble fluoride (Fins) concentrations were calculated. All the results were expressed in ppm $\left(\mu \mathrm{g} \mathrm{F}^{-} / \mathrm{g} ; \mathrm{w} / \mathrm{w}\right)$.

\section{Statistical analysis}

The experimental design used took into consideration the following factors: dentifrice, storage temperature and storage time. Considering the absence of normality through the Shapiro-Wilks test, the non-parametric technique of the part subdivided into time was used. For the multiple comparisons the level of $5 \%$ of significance was considered $(\mathrm{p} \leq 0.05)$, and the Software Analysis System (SAS)* was used.

\section{RESULTS}

During the evaluation period (August/97 to July/98) the ambient temperature ranged from 26.6 to 30.1 , an average of $28.9^{\circ} \mathrm{C}$. Under air conditioning it ranged from 25.6 to 28.7 , a mean of $26.3^{\circ} \mathrm{C}$.

Graph 1 shows the results (average of $n=6$ ) of total fluoride concentration (TF), total soluble (TSF), ionizable (MFP) and insoluble (Fins) in the dentifrices stored over time in the ambient temperature. With regard to $\mathrm{TF}$ concentration there was no statistically significant change over time $(p>0.05)$ and the results are in accordance with the current National Sanitary Vigilance Agency (ANVISA) regulation ${ }^{3}$.

The TSF concentrations in the dentifrices Close-up ${ }^{\oplus}$, Crest $^{\oplus}$ and Tandy ${ }^{\circledast}$ did not show significant changes over time ( $\mathrm{p}>0.05)$. The dentifrices Colgate MFP-Ca ${ }^{\oplus}$, Gessy $^{\oplus}$, Signal $^{\oplus}$ and Sorriso ${ }^{\oplus}$ showed a decrease of TSF concentration as a result of storage time in ambient temperature $(\mathrm{p}<0.05)$. In Graph 1 it may also be seen that the MFP concentration of the dentifrices Colgate ${ }^{\oplus}$, Gessy $^{\oplus}$, Signal $^{\oplus}$ and Sorriso ${ }^{\oplus}$ diminishes at the same time that there was an increase in Fins.

Graph 2 shows the results of fluoride concentration in the dentifrices when they were stored over time under air conditioning. With regard to TF concentration, there was no statistically significant change as a result of time $(p>0.05)$. The toothpastes Close-up ${ }^{\oplus}$, Crest ${ }^{\oplus}$ and Tandy ${ }^{\circledast}$ showed the same pattern as that observed for ambient temperature with regard to TSF, while Colgate MFP-Ca ${ }^{\oplus}$, Gessy $^{\oplus}$, Signal $^{\oplus}$ and Sorriso ${ }^{\oplus}$ showed a significant decrease as a result of time. In addition, Graph 2 also shows that the MFP concentration of the dentifrices Colgate MFP-Ca ${ }^{\circledast}$, Gessy ${ }^{\circledast}$, Signal ${ }^{\circledast}$ and Sorriso ${ }^{\circledast}$ diminished at the same time that there was an increase in Fins.

With regard to MFP, both at ambient temperature and under air conditioning all the dentifrices containing this type of fluoride showed decrease in concentration as a result of time (Graphs 1 and 2). Comparing this variable between the two ambient conditions, the differences were not significant for Close-up ${ }^{\circledast}$ at all of the times; in Colgate MFP-Ca ${ }^{\circledast}$ there was a small loss at all times under air conditioned temperature, but the differences were only significant at the times of 8 and 12 months; Gessy $^{\circledR}$, Signal ${ }^{\circledast}$ showed the smallest losses also under air conditioning, these being significant at the times of 4,8 and 12 months.

*SAS Institute Inc. SAS User's Guide Statistics, Version 5 Edition. Cary, NC: SAS Institue Inc.; 1985. 956p. 

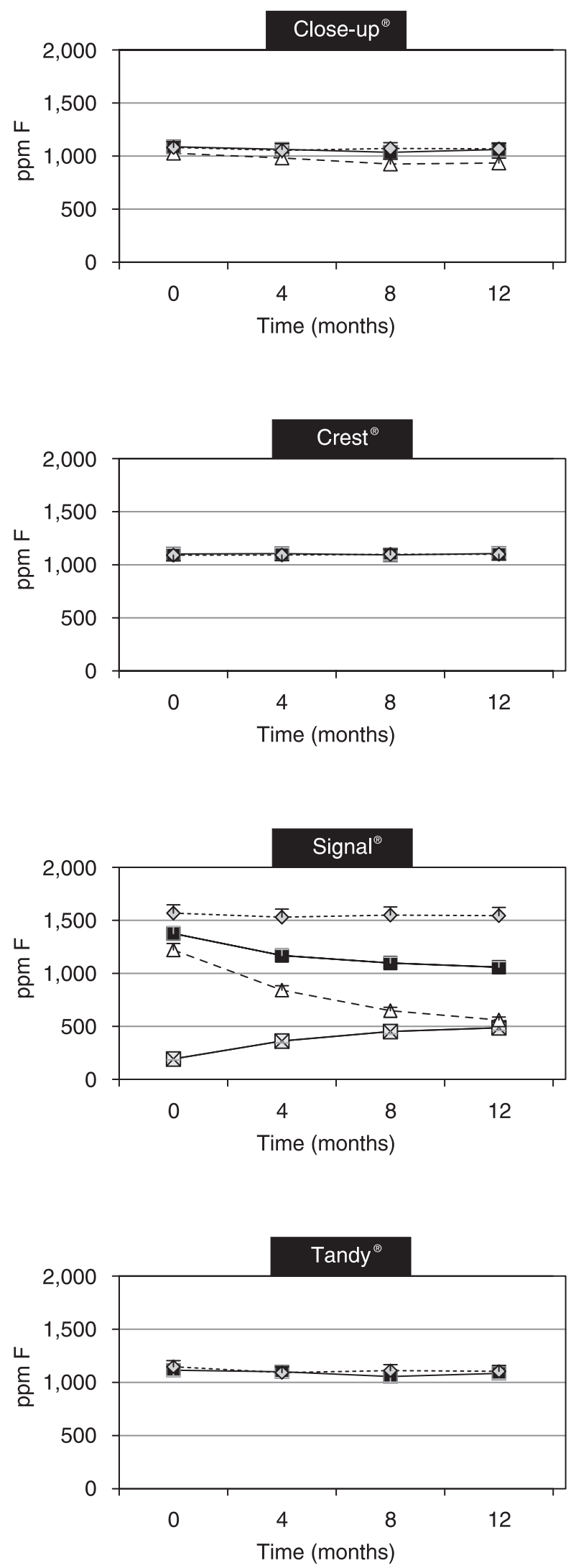
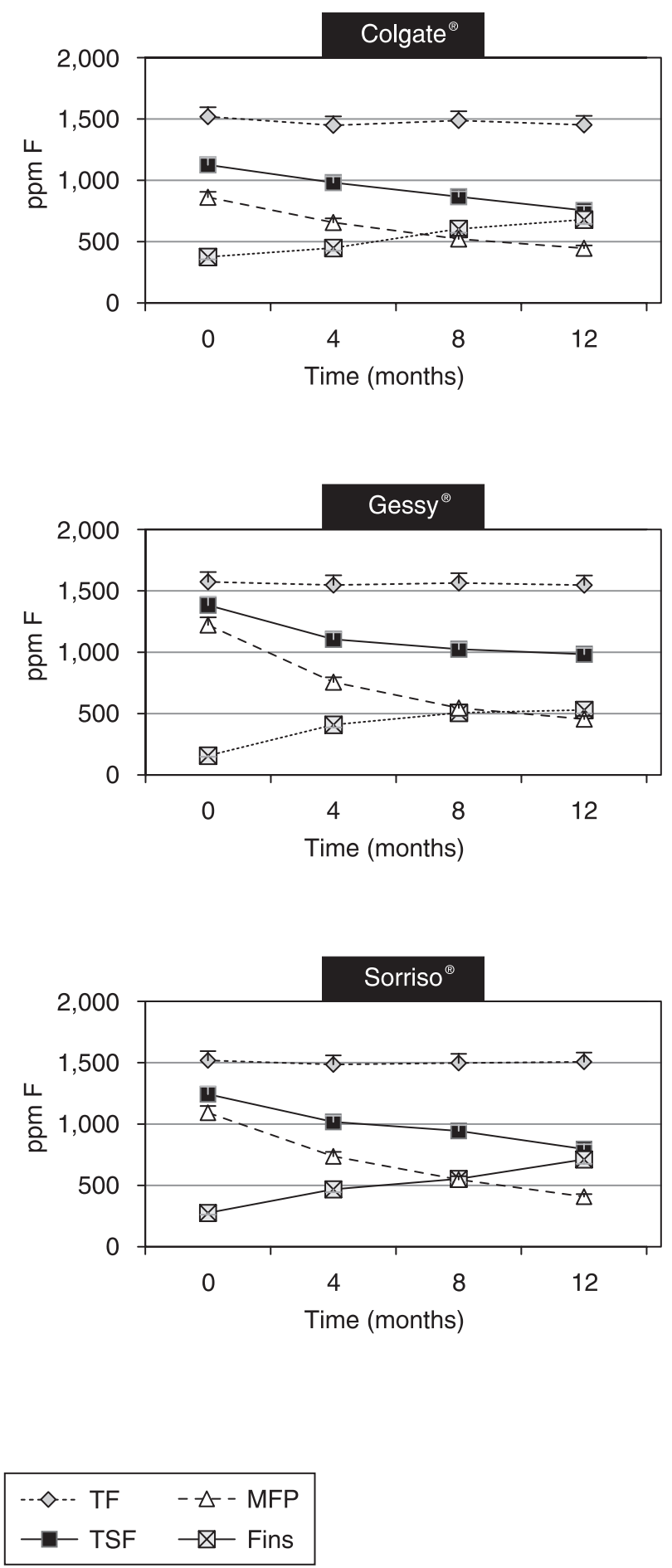

GRAPH 1 - Concentration (average, SD, $\mathrm{n}=6$ ) of the different forms of fluoride in the dentifrices stored over time (months) at ambient temperature. TF: total fluoride; TSF: total soluble fluoride; MFP: sodium monofluorophosphate; Fins: insoluble fluoride. 

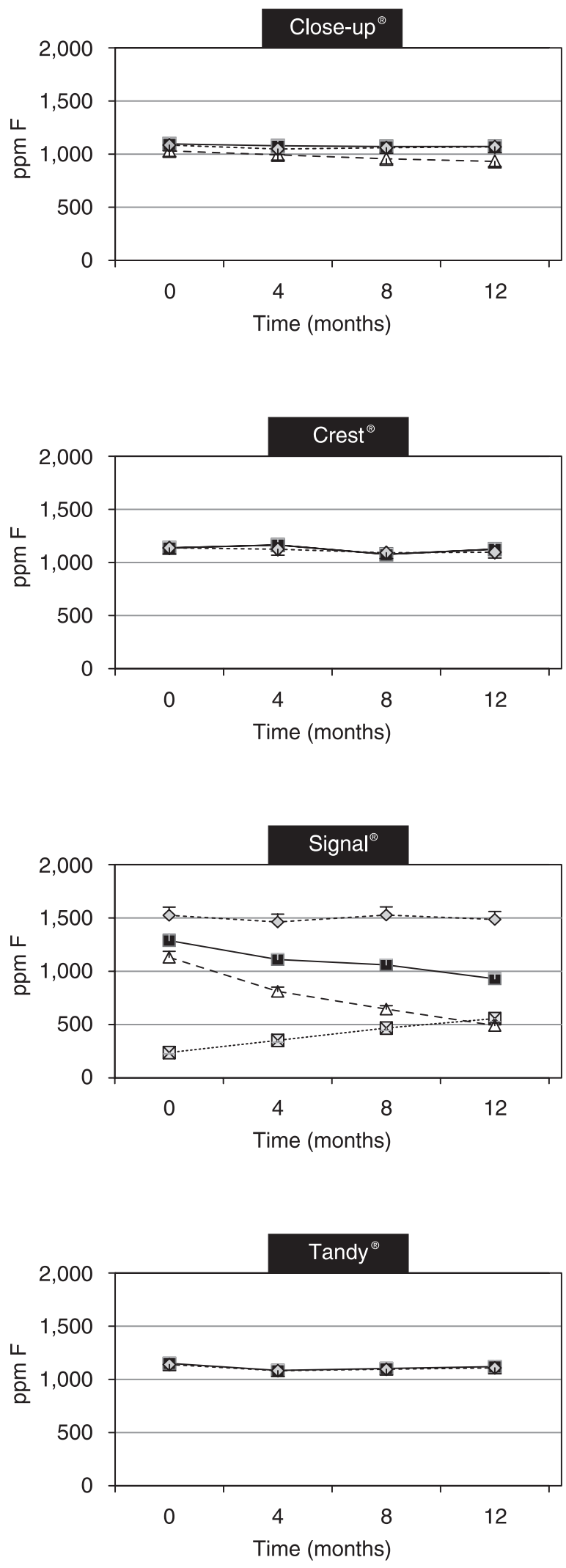
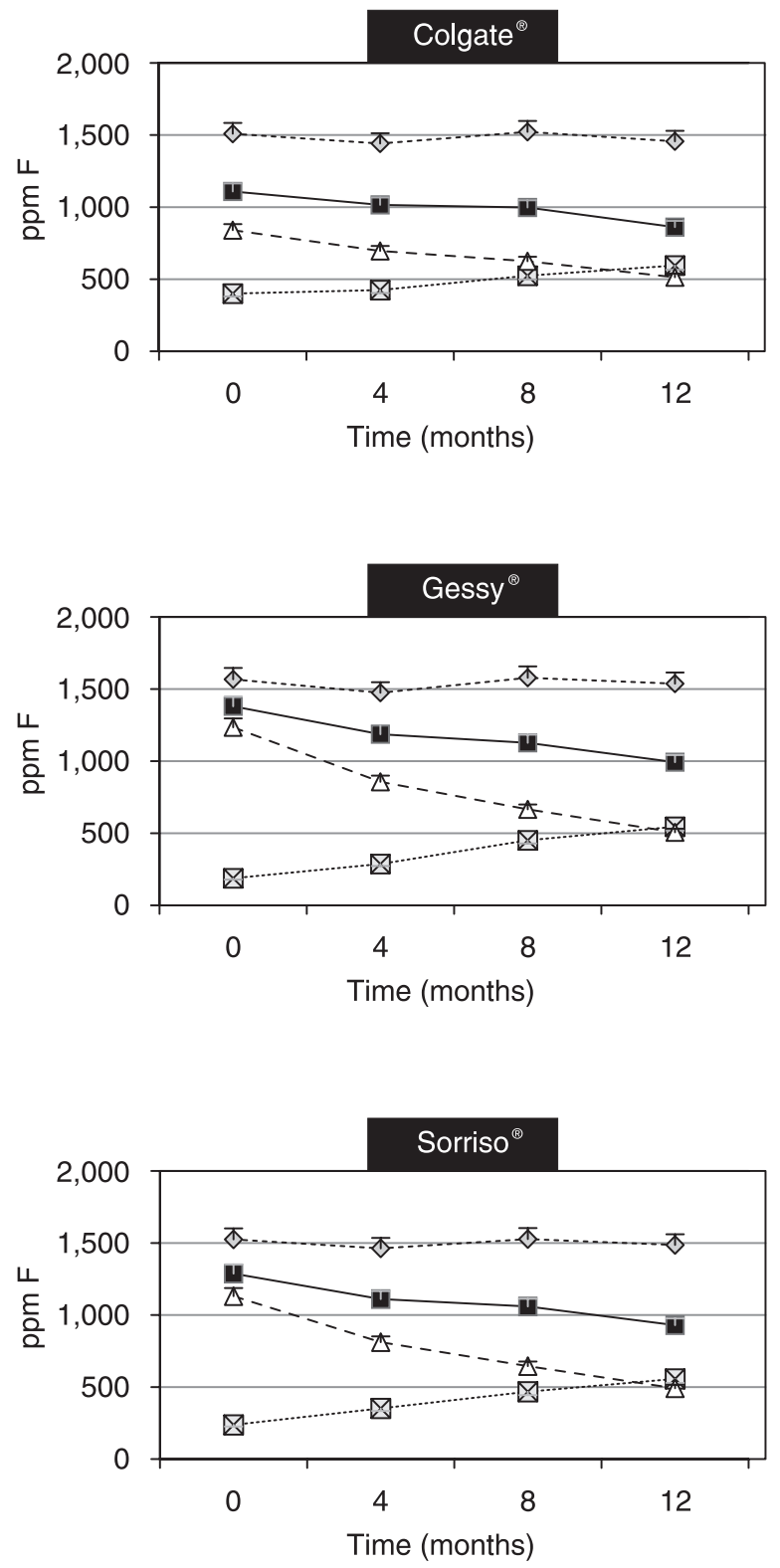

\begin{tabular}{|ll}
\hline$-\diamond-$ TF & $-\bowtie-$ MFP \\
$-\square$ TSF & $-\otimes-$ Fins
\end{tabular}

GRAPH 2 - Concentration (average, SD, $\mathrm{n}=6$ ) of the different forms of fluoride in the dentifrices stored over time (months) at air conditioning. TF: total fluoride; TSF: total soluble fluoride; MFP: sodium monofluorophosphate; Fins: insoluble fluoride. 
Conde NCO, Rebelo MAB, Cury JA. Evaluation of the fluoride stability of dentifrices sold in Manaus, AM, Brazil. Pesqui Odontol Bras $2003 ; 17(3): 247-53$.

The results of $\mathrm{F}^{-}$concentration (mathematically it is the difference between TSF and MFP) were not shown to make the figures clearer, but in the dentifrices Close-up ${ }^{\oplus}$, Colgate MFP-Ca ${ }^{\oplus}$, Gessy ${ }^{\circledR}$, Sig$\mathrm{nal}^{\oplus}$ and Sorriso ${ }^{\circledast}$ there was an increase as a result of storage time and in the dentifrices $\mathrm{Crest}^{\oplus}$ and Tandy ${ }^{\circledast}$ there was no significant alteration.

\section{DISCUSSION}

According to Rölla et al. ${ }^{19}$ (1991), only one method of dental caries prevention is common to all countries that showed a reduction in the prevalence of this disease: the use of fluoridated dentifrice. However, in order for the fluoridated dentifrice to attain its therapeutic effect in terms of caries prevention, it is necessary for it to meet minimum requirements in terms of availability and stability of fluoride ${ }^{1}$. Thus, in the past, dentifrices were unable to reduce dental caries due to the formulations containing free ionic fluoride and calcium together $^{12}$. As a consequence, the formation of low solubility products occurred in the formulation with the inactivation of fluoride in the product ${ }^{16}$. Furthermore, this reaction is fast and in a week $60-90 \%$ of the fluoride would be insoluble ${ }^{14}$.

The first relevant result of this study was to show that storage conditions are important to the stability of fluoride in the dentifrices and for a difference of only $2.6^{\circ} \mathrm{C}$ between the tested storage conditions, significant losses of soluble fluoride were found ( $<<0.05)$. This leads us to suppose that under more drastic temperature conditions, a greater loss of soluble fluoride would occur in some dentifrices.

With regard to total fluoride (TF) there was no variation in concentration as a result of storage time under the two conditions studied. In addition, the results are in accordance with the packaging specifications reported by the manufacturer. This non-variation of the total was expected, as the total never changes, but there may be chemical changes from one form of fluoride to another as a result of product instability.

The concentration of total soluble fluoride (TSF) in the dentifrices Close-up ${ }^{\circledast}, \mathrm{Crest}^{\oplus}$ and Tandy ${ }^{\circledast}$ did not undergo alterations as a result of time. This should be attributed to the fact that these toothpastes have NaF/silica $\left(\mathrm{Crest}^{\oplus}\right.$ and $\mathrm{Tandy}^{\circledR}$ ) and MFP/silica (Close-up ${ }^{\circledR}$ ) in their formulation. Of these dentifrices, Duarte et al. ${ }^{11}$ (1999) analyzed the dentifrice Close-up ${ }^{\circledast}$, and the present result is in agreement with that report. Silica allows the fluoride concentration in a dentifrice to remain stable, independent of whether it is in $\mathrm{F}^{-}$form or in MFP. On the other hand, the decrease of TSF in the dentifrices Colgate MFP-Ca ${ }^{\circledast}$, Gessy $^{\circledast}$, Signal ${ }^{\circledR}$ and Sorriso $^{\circledast}$ should be attributed to the fact that these toothpastes are composed of MFP, which undergoes hydrolysis over time producing free fluoride $\left(\mathrm{F}^{-}\right)$ which in turn is inactivated by the $\mathrm{Ca}^{++}$of the abrasive $e^{5,13,14}$.

It should be pointed out that in this study an evaluation was made over the period of one year, but it should be emphasized that the estimated time that dentifrices stay in a supermarket is approximately 3 months. This time would be sufficient to prevent a loss of soluble fluoride and thus the manufacturers' strategy for guaranteeing an anti-caries concentration seems to be to produce dentifrices with $1,500 \mu \mathrm{g} \mathrm{F}^{-} / \mathrm{g}$, which is the maximum permitted by law ${ }^{3}$. Thus, this would compensate the fluoride inactivation by the abrasive, and a soluble concentration of $1,000-1,100 \mu \mathrm{g} \mathrm{F} / \mathrm{g}$ would be guaranteed by the time that the toothpaste is consumed. Nevertheless, although the city of Manaus has a tropical climate, the maximum average temperature at which the dentifrices were evaluated was $30.1^{\circ} \mathrm{C}$. Therefore, under higher temperature conditions one would expect a greater loss of active fluoride in a shorter period of time and this could be relevant for the dentifrices with $\mathrm{MFP} / \mathrm{CaCO}_{3}$.

Although the data of this study have shown a decrease of TSF over the storage time, the minimum concentration attained has been able to contribute towards the decline of dental caries that has occurred in Brazil during the last years ${ }^{15}$. However, in order for this decline in caries to continue occurring, the control and adequate regulation of dentifrices is mandatory. The results obtained in this study showed that all the dentifrices complied with the administrative ruling in force ${ }^{3}$, a maximum of $0.15 \%$ of TF. However, as the need for fluoride in the dentifrice to be soluble (active against caries) was abolished, there is no longer any guarantee that the population will be using a product with a minimum concentration of active fluoride to reduce caries; a recent publication showed this to be a real risk $^{17}$.

With regard to insoluble fluoride (Fins), the results of this study showed that in the dentifrices containing $\mathrm{MFP} / \mathrm{CaCO}_{3}$ there was already an average of $17 \%$ of Fins when the product was purchased. After a year at ambient temperature this increased to $40 \%$, while in the samples stored under 
Conde NCO, Rebelo MAB, Cury JA. Evaluation of the fluoride stability of dentifrices sold in Manaus, AM, Brazil. Pesqui Odontol Bras 2003;17(3):247-53.

air conditioning the increase attained 35\% (Graphs 1 and 2). This may be explained by the hydrolysis of MFP that releases free ionic fluoride, which links with the calcium of the abrasive resulting in insoluble fluoride. The behavior observed in this study for dentifrices with MFP-Ca has been reported in the literature $e^{2,5,7,11,13,14,20}$.

\section{CONCLUSIONS}

1. In terms of fluoride stability, the silica-based dentifrices, either containing NaF or MFP, were shown to be stable whether they were stored at ambient temperature or under air conditioning.

2. The calcium carbonate-based dentifrices containing MFP showed a decrease in TSF concentration and an increase in the percentage of Fins over time, and this was more evident when stored at ambient temperature.

\section{REFERENCES}

1. ADA. Council on Dental Therapeutics. Guidelines for the acceptance of fluoride-containing dentifrices. J Am Dent Assoc 1985;110:545-7.

2. Athanassouli TM, Papastathopoulos DS. A laboratory evaluation of fluoride dentifrices used in Greece. Community Dent Oral Epidemiol 1978;6:185-90.

3. Brasil, Ministério da Saúde. Secretaria Nacional de Vigilância Sanitária. Resolução n ${ }^{\circ} 79$ de 28 de agosto de 2000. DO 169 de 31/08/2000. p. 1415-537.

4. Cury JA, Guimarães LOC, Arbex ST, Moreira BW. Análise dos dentifrícios fluoretados: concentração e formas químicas de fluoretos encontrados em produtos brasileiros. Rev Assoc Paul Cir Dent 1981;35:142-7.

5. Cury JA. Estabilidade do flúor nos dentifrícios brasileiros. Rev Gaúcha Odontol 1986;34:430-2.

6. Cury JA. Avaliação de um gel dentifrício contendo xilitol e flúor. Rev Bras Odontol 1987;44:36-40.

7. Cury JA. Dentifrícios fluoretados no Brasil. Rev Gaúcha Odontol 1989;37:139-42.

8. Cury JA. Dentifrícios fluoretados no mercado brasileiro e seu potencial como método preventivo. Associação Brasileira de Odontologia Preventiva (ABOPREV - Gestão 89-91), publicação avulsa, 1989. p. 1-8.

9. Cury JA. Cárie e o creme dental. Jornal da ABOPREV Especial, Ano IX, out. 1998. p. 2.

10. Cury JA. Uso do flúor e o controle da cárie como doença. In: Baratieri LN, Monteiro S, Andrada MAC, Vieira LCC, Ritter AV, Cardoso AC. Odontologia Restauradora: fundamentos e possibilidades. São Paulo: Santos; 2001. p. 34-68.

11. Duarte FF, Pisaneschi E, Cury JA. Avaliação do flúor dos dentifrícios mais consumidos no Brasil e comercializados nas cinco regiões do País. Rev ABOPREV 1999;2:3-10.
3. However, all the dentifrices analyzed comply with Resolution No. 79/2000 of the ANVISA, Brasília-DF, which needs to be modified because it only requires compliance with regard to the quantity of fluoride in dentifrices and does not consider its quality.

\section{ACKNOWLEDGEMENTS}

To Mr. Waldomiro Vieira Filho, technician of the FOP-UNICAMP Oral Biochemical Laboratory, for help with the initial analyses; and to Professor, PhD, Rosana Cristina Pereira Parente, Federal University of Amazonas (UFAM), for the statistical analysis; and to Professor, PhD, Jose Nunes Mello, UFAM, for help with drawing up the graphs. This work is part of the dissertation of the first author presented as a requisite for obtaining the title of Master in Tropical Pathology, UFAM.

12. Ericsson Y. Fluorides in dentifrices: investigations using radioactive fluorine. Acta Odontol Scand 1961;19:41-77.

13. Freitas JF. Fluoride stability in toothpastes. Aust Dent J 1984;29:30-5.

14. Hattab FN. The state of fluorides in toothpastes. J Dent 1989; 17:47-54.

15. Narvai PC, Frazão P, Castellanos RA. Declínio na experiência de cárie em dentes permanentes de escolares brasileiros no final do século XX. Odontologia e Sociedade 1999;1:25-9.

16. Nören B, Harse C. The stability of the monofluorphosphate and fluoride ions in dentifrice containing calcium carbonate. J Soc Cosmet Chem 1974;25:3-11.

17. Orth MR, Assaf AV, Zanin L, Mialhe FL, Klein AL, Medina MRJ, et al. Concentração de flúor nos principais dentifrícios comercializados no Brasil e impacto da nova portaria de regulamentação. Revista Odonto Ciência 2001; 16:27-33.

18. Richards A, Banting DW. Fluoride toothpastes. In: Fejerskov O, Ekstrand J, Burt BA. Fluoride in Dentistry. $2^{\text {nd }}$ ed. Copenhagen: Munksgaard; 1996. p. 352-72.

19. Rölla G, Oggard B, Cruz RA. Clinical effect and mechanism of cariostatic action of fluoride containing toothpaste: a review. Int Dent J 1991;41:171-4.

20. Sarmiento RV, Issáo M, Cury JA. Estudio de la disponibilidad y estabilidad de flúor de los dentífricos comercializados en el Perú. Rev Estomatol Herediana 1994;4:12-20.

21. ten Cate JM, Featherstone JDB. Physicochemical aspects of fluoride-enamel interactions. In: Fejerskov O, Ekstrand J, Burt BA. Fluoride in Dentistry. $2^{\text {nd }}$ ed. Copenhagen: Munksgaard; 1996. p. 352-72. 